\begin{tabular}{|c|c|c|}
\hline Case Reports in & \multicolumn{2}{|c|}{ Case Rep Gastroenterol 2018;12:240-246 } \\
\hline Gastroenterology & $\begin{array}{l}\text { DOI: } 10.1159 / 000488194 \\
\text { Published online: June 5, } 2018\end{array}$ & $\begin{array}{l}\text { ( } 2018 \text { The Author(s) } \\
\text { Published by S. Karger AG, Basel } \\
\text { www.karger.com/crg }\end{array}$ \\
\hline & $\begin{array}{l}\text { This article is licensed under } \\
\text { International License (CC BY- } \\
\text { Usage and distribution for com }\end{array}$ & $\begin{array}{l}\text { nons Attribution-NonCommercial } 4.0 \\
\text { ger.com/Services/OpenAccessLicense). } \\
\text { uires written permission. }\end{array}$ \\
\hline
\end{tabular}

\title{
Mixed Neuroendocrine Carcinoma and Squamous Cell Carcinoma of the Colon: Case Report and Literature Review
}

\author{
Shinya Munakata Yuta Murai Akihiro Koizumi Hisaki Kato \\ Riku Yamamoto Shuhei Ueda Satoshi Tokuda Shunsuke Sakuraba \\ Tomoyuki Kushida Hajime Orita Mutsumi Sakurada Hiroshi Maekawa \\ Koichi Sato
}

Department of Surgery, Juntendo Shizuoka Hospital, Juntendo University School of

Medicine, Izunokuni, Japan

\section{Keywords}

Neuroendocrine carcinoma $\cdot$ Squamous cell carcinoma

\begin{abstract}
Neuroendocrine carcinoma (NEC) of the colon is very rare, and squamous cell carcinoma (SCC) of colon cancer is rare. We recently treated a patient with both NEC and SCC that initially presented as multiple unresectable liver and lung metastases. A 68-year-old Japanese man was referred to our hospital because of diarrhea with descending colon cancer obstruction. He underwent a left colectomy. Based on immunohistochemistry results, we diagnosed mixed NEC and SCC, the primary lesion location of which was probably the lung in the final pathologic examination. He began systemic palliative chemotherapy with CDDP and CPT-11. After 3 months of treatment, shown the progressive disease, we started CDDP and VP-16. The patient was not eligible for additional chemotherapy after 2 months.




\section{Case Reports in Gastroenterology}

Case Rep Gastroenterol 2018;12:240-246

DOI: $10.1159 / 000488194$

(c) 2018 The A www.karger.com/crg

Munakata et al.: Mixed Neuroendocrine Carcinoma and Squamous Cell Carcinoma of the Colon: Case Report and Literature Review

\section{Introduction}

Neuroendocrine tumors (NETs) are a rare type of tumor that originates in the cells of the neuroendocrine system. Neuroendocrine carcinoma (NEC) of the colon and rectum is also a rare NET type that accounts for $<2.0 \%$ of all colorectal malignancies [1, 2]. The 2010 World Health Organization (WHO) classification categorizes NETs according to the proliferation fraction (the mitotic count or the Ki67 index) into NET G1 (carcinoid), G2, and NEC (small cell or large cell) [3].

Squamous cell carcinoma (SCC) of the gastrointestinal tract is a rare occurrence and usually involves the esophagus or anal canal. SCC accounts for $0.1-0.25 \%$ per 1,000 cases of colorectal carcinoma [3]. Mixed adenoneuroendocrine carcinoma was defined by the WHO in 2010 as a neoplasm with dual adenocarcinomatous and neuroendocrine differentiation, with each component accounting for at least $30 \%$ of the tumor. Here we present the unique case of a patient with NEC and SCC of the descending colon with multiple lung and liver metastases.

\section{Case Presentation}

A 68-year-old Japanese man with a noncontributory medical history was admitted to our hospital because of diarrhea. No apparent abnormalities were found on physical examination at admission, except for abdominal distention. Laboratory data on admission showed the following: erythrocyte count $321 \times 10^{4} / \mathrm{mm}^{3}$ (normal 380-480), hemoglobin $9.3 \mathrm{~g} / \mathrm{dL}$ (normal 12-16), leukocyte count $7,000 / \mathrm{mm}^{3}$ (normal $4,000-9,000$ ), platelet count $28.7 \times 10^{4} / \mathrm{mm}^{3}$ (normal 10-40), serum total protein $7.1 \mathrm{~g} / \mathrm{dL}$ (normal 6.7-8.3), total bilirubin $0.3 \mathrm{mg} / \mathrm{dL}$ (normal 0.2-1.2), aspartate aminotransferase 26 IU/L (normal 12-28), alanine aminotransferase 14 IU/L (normal 8-34), alkaline phosphatase 287 IU/L (normal 115-274), $\gamma$-glutamyltranspeptidase $90 \mathrm{IU} / \mathrm{L}$ (normal 12-48), serum amylase $125 \mathrm{IU} / \mathrm{L}$ (normal 37-125), blood urea nitrogen $24.7 \mathrm{mg} / \mathrm{dL}$ (normal 8-20), creatinine $1.0 \mathrm{mg} / \mathrm{dL}$ (normal 0.5-0.9), and C-reactive protein $2.1 \mathrm{mg} / \mathrm{dL}$ (normal 0-0.3). The serum level of the tumor marker carcinoembryonic antigen was $18 \mathrm{ng} / \mathrm{mL}$ (normal 0-5), and the carbohydrate antigen level was $9.0 \mathrm{U} / \mathrm{mL}$ (normal 0-37).

The dilatation was further assessed with a barium enema examination, which demonstrated an apple core sign at the descending colon that was causing a high-grade obstruction (Fig. 1a). Colonoscopy demonstrated an obstructive descending colon cancer (Fig. 1b). Colonoscopic biopsy from the descending colon tumor was inconclusive. Upper gastrointestinal endoscopic findings were unremarkable. Computed tomography of the chest and abdomen demonstrated a 4-cm enhancing high-density mass at the descending colon mass and multiple distant metastases of the liver and lung (Fig. 1c, d).

The metastatic tumor was considered unresectable, and we performed a left colectomy for improvement of the diarrhea and abdominal distention. Gross examination of the resected specimen showed a Bormann type II (ulcerofungating type) cancer, $3.5 \times 3.5 \mathrm{~cm}$, presenting in the descending colon (Fig. 2a). Immunohistochemical staining of the SCC was positive for p40 and diffusely positive for CK5/6. These tumor cells stained positive for CK7 and negative for CK20 (Fig. 3a-d). Tumor cells from both foci stained positive for thyroid transcription factor 1. In addition, other parts of the tumor cells were diffusely positive for synaptophysin and CD56 and weakly positive for chromogranin A, with a Ki67 index of 80\%, indicating nuclear reactivity (Fig. 3e-g). About 30\% of the tumor cells were SCC and $70 \%$ of the tumor cells were NEC. 


\section{Case Reports in Gastroenterology}

Case Rep Gastroenterol 2018;12:240-246

DOI: $10.1159 / 000488194$

(c) 2018 The Author(s). Published by S. Karger AG, Basel www.karger.com/crg

Munakata et al.: Mixed Neuroendocrine Carcinoma and Squamous Cell Carcinoma of the Colon: Case Report and Literature Review

The final pathology report showed a mixed NEC and SCC, stage T3N2M1, with 6 out of 8 lymph nodes containing tumor. Based on the performance status of 0 , the patient began systemic palliative chemotherapy with CDDP and CPT-11 (CDDP $30 \mathrm{mg} / \mathrm{m}^{2}$ of body surface and irinotecan $60 \mathrm{mg} / \mathrm{m}^{2}$, every 2 weeks). Six cycles of chemotherapy were administered without major toxicity. After 3 months of treatment, the patient underwent a restaging computed tomography scan, which showed progressive disease. Though we started CDDP and VP-16 (CDDP $80 \mathrm{mg} / \mathrm{m}^{2}$ of body surface and etoposide $100 \mathrm{mg} / \mathrm{m}^{2}$, every 2 weeks), he was not eligible for additional chemotherapy after four cycles.

\section{Discussion}

NEC and SCC of the colon is an exceptionally rare tumor. Histologically, it is composed of a variable combination of sheet architecture in the form of NEC and squamous architecture in the form of keratinization and cancer pearl. The published literature suggests that usual colon adenocarcinomas are largely positive for intestinal markers (CK20) and less commonly positive for gastropancreatobiliary markers (CK7) [4]. Our pathologic findings were different from general cases. Typical markers to characterize SCC are p40 and CK5/6 [5]. These makers were positive for our case. On the other hands, as far as the NETs are concerned, NETs account for $0.4 \%$ of all colorectal neoplasm [6]. The location of colonic NETs is approximately at the descending colon and rectum where it occupied $27 \%$ of the gastrointestinal tract [7]. The most sensitive and specific general NET markers, chromogranin A, synaptophysin, and CD56, are extremely useful to confirm the diagnosis [8, 9]. In 2009, it was shown that somatostatin analogs delay tumor progression in patients with well-differentiated NETs [10]. As the currently available somatostatin analogs bind preferentially to somatostatin receptor 2a (SSTR-2a), which is the most widely expressed receptor subtype in NETs, SSTR-2a immunohistochemistry is considered to be the definitive clinical response marker for somatostatin analog therapy [9]. Though we could not obtain the SSTR-2a antibody, SSTR-2a does not tend to express in NEC [9]. Macroscopically, in our case the colon was considered the primary location, but CD7/20 staining and thyroid transcription factor 1 showed that the primary tumor was of lung origin.

The National Comprehensive Cancer Network guidelines recommend CDDP/VP-16 or CPT-11/CDDP for unresectable NEC. These chemotherapies were derived from the regimen for small cell carcinoma of the lung [11]. Although the Japan Clinical Oncology Group conducted a randomized phase III trial comparing CDDP/VP-16 versus CPT-11/CDDP in patients with advanced NEC of the digestive system (JCOG1213), this study is ongoing and the therapeutic efficacy of these regimens side by side has not yet been clarified. Recently, the application of the treatment guidelines for colorectal cancer was reported, and a case was described in whom 5-FU-based therapy was more effective than standard chemotherapy (CDDP/VP-16 or CPT-11/VP-16) for advanced NEC of the digestive system because these tumors had an adenocarcinoma component [9]. However, our case did not have an adenocarcinoma component but SCC, and chemotherapy of the present case was considered to be appropriate.

In conclusion, we report an NET of the colon that coexisted with an SCC, suggesting a possible common link between the pathogenesis of these two distinct entities. However, future research is required to determine the pathogenesis of these synchronous tumors. 


\section{Case Reports in Gastroenterology}

\begin{tabular}{l|l}
\hline DOI: 10.1159/000488194 & @ 2018 The Author(s). Published by S. Karger AG, Basel \\
\hline
\end{tabular}
www.karger.com/crg

Munakata et al: Mixed Neuroendocrine Carcinoma and Squamous Cell Carcinoma of the Colon: Case Report and Literature Review

\section{Statement of Ethics}

Written informed consent was obtained from the patient for publication of this case report and any accompanying images.

\section{Disclosure Statement}

The authors declare no conflict of interest.

\section{Author Contributions}

Data acquisition: S. Munakata, Y. Murai, A. Koizumi, H. Kato, R. Yamamoto, S. Ueda, S. Tokuda, S. Sakuraba, T. Kushida, H. Orita, M. Sakurada, H. Maekawa; drafting of the manuscript: S. Munakata, K. Sato; critical revision of the manuscript: S. Munakata.

\section{References}

1 Bernick PE, Klimstra DS, Shia J, Minsky B, Saltz L, Shi W et al. Neuroendocrine carcinomas of the colon and rectum. Dis Colon Rectum. 2004 Feb;47(2):163-9.

2 Shafqat H, Ali S, Salhab M, Olszewski AJ. Survival of patients with neuroendocrine carcinoma of the colon and rectum: a population-based analysis. Dis Colon Rectum. 2015 Mar;58(3):294-303.

3 Vyas N, Ahmad S, Bhuiyan K, Catalano C, Alkhawam H, Sogomonian R et al. Primary squamous cell carcinoma of the rectum: a case report and literature review. J Community Hosp Intern Med Perspect. 2016 Jul;6(3):31708.

4 Kato T, Terashima T, Tomida S, Yamaguchi T, Kawamura H, Kimura N et al. Cytokeratin 20-positive large cell neuroendocrine carcinoma of the colon. Pathol Int. 2005 Aug;55(8):524-9.

5 Rekhtman N, Ang DC, Sima CS, Travis WD, Moreira AL. Immunohistochemical algorithm for differentiation of lung adenocarcinoma and squamous cell carcinoma based on large series of whole-tissue sections with validation in small specimens. Mod Pathol. 2011 Oct;24(10):1348-59.

6 Konishi T, Watanabe T, Kishimoto J, Kotake K, Muto T, Nagawa H; Japanese Society for Cancer of the Colon and Rectum. Prognosis and risk factors of metastasis in colorectal carcinoids: results of a nationwide registry over 15 years. Gut. 2007 Jun;56(6):863-8.

7 Klimstra DS, Modlin IR, Coppola D, Lloyd RV, Suster S. The pathologic classification of neuroendocrine tumors: a review of nomenclature, grading, and staging systems. Pancreas. 2010 Aug;39(6):707-12.

8 Klimstra DS. Pathology reporting of neuroendocrine tumors: essential elements for accurate diagnosis, classification, and staging. Semin Oncol. 2013 Feb;40(1):23-36.

9 Komatsubara T, Koinuma K, Miyakura Y, Horie H, Morimoto M, Ito $\mathrm{H}$ et al. Endocrine cell carcinomas of the colon and rectum: a clinicopathological evaluation. Clin J Gastroenterol. 2016 Feb;9(1):1-6.

10 Rinke A, Müller HH, Schade-Brittinger C, Klose KJ, Barth P, Wied M et al.; PROMID Study Group. Placebocontrolled, double-blind, prospective, randomized study on the effect of octreotide LAR in the control of tumor growth in patients with metastatic neuroendocrine midgut tumors: a report from the PROMID Study Group. J Clin Oncol. 2009 Oct;27(28):4656-63.

11 Noda K, Nishiwaki Y, Kawahara M, Negoro S, Sugiura T, Yokoyama A et al.; Japan Clinical Oncology Group. Irinotecan plus cisplatin compared with etoposide plus cisplatin for extensive small-cell lung cancer. $\mathrm{N} \mathrm{Engl} \mathrm{]}$ Med. 2002 Jan;346(2):85-91.

S. Munakata is the first and K. Sato the senior author. 


\section{Case Reports in Gastroenterology}
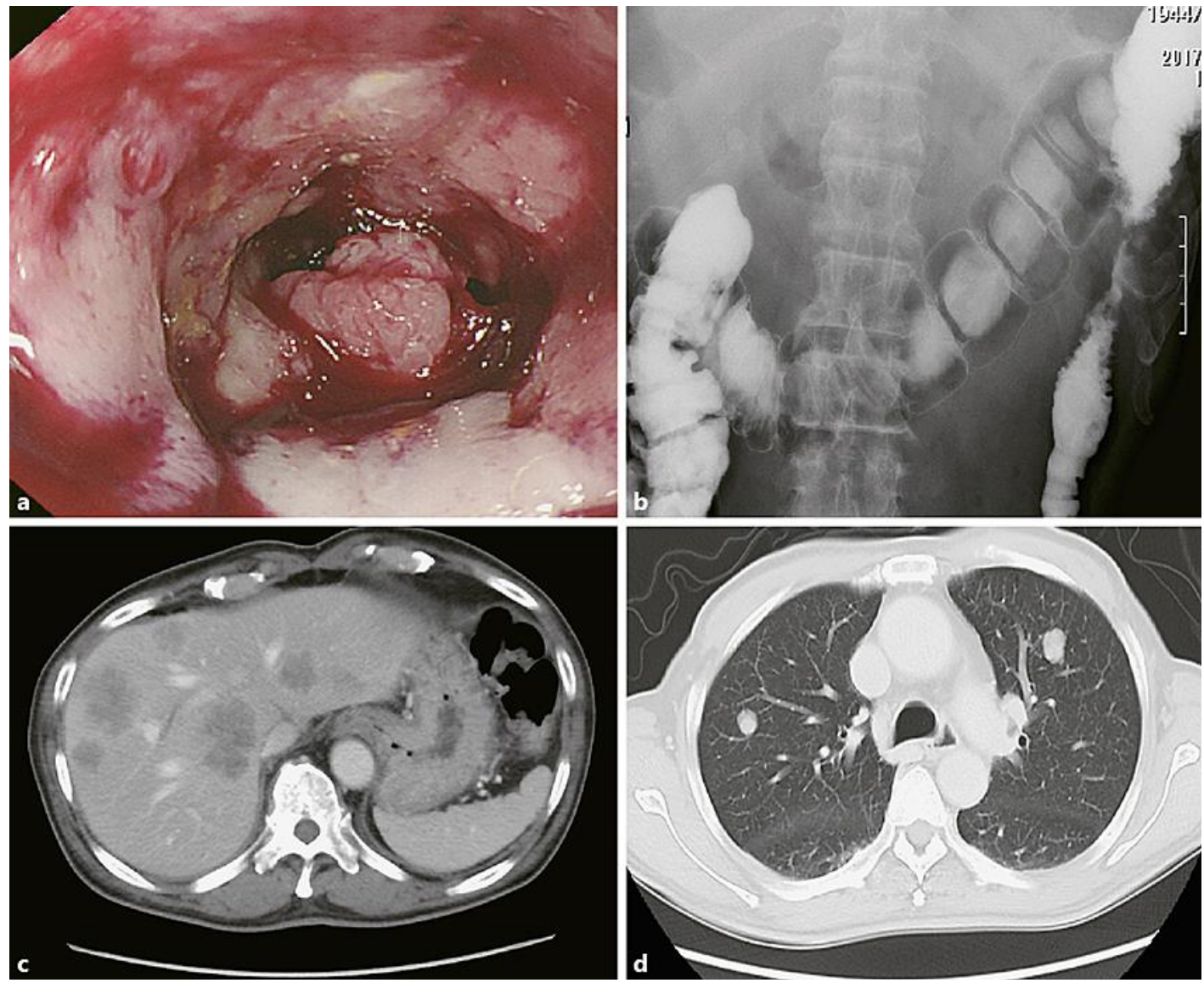

Fig. 1. a, b Endoscopy (a) and barium enema (b) showed an obstructive cancer in the descending colon. c, $\mathbf{d}$ Computed tomography showed the multiple liver and lung metastases. 


\section{Case Reports in Gastroenterology}
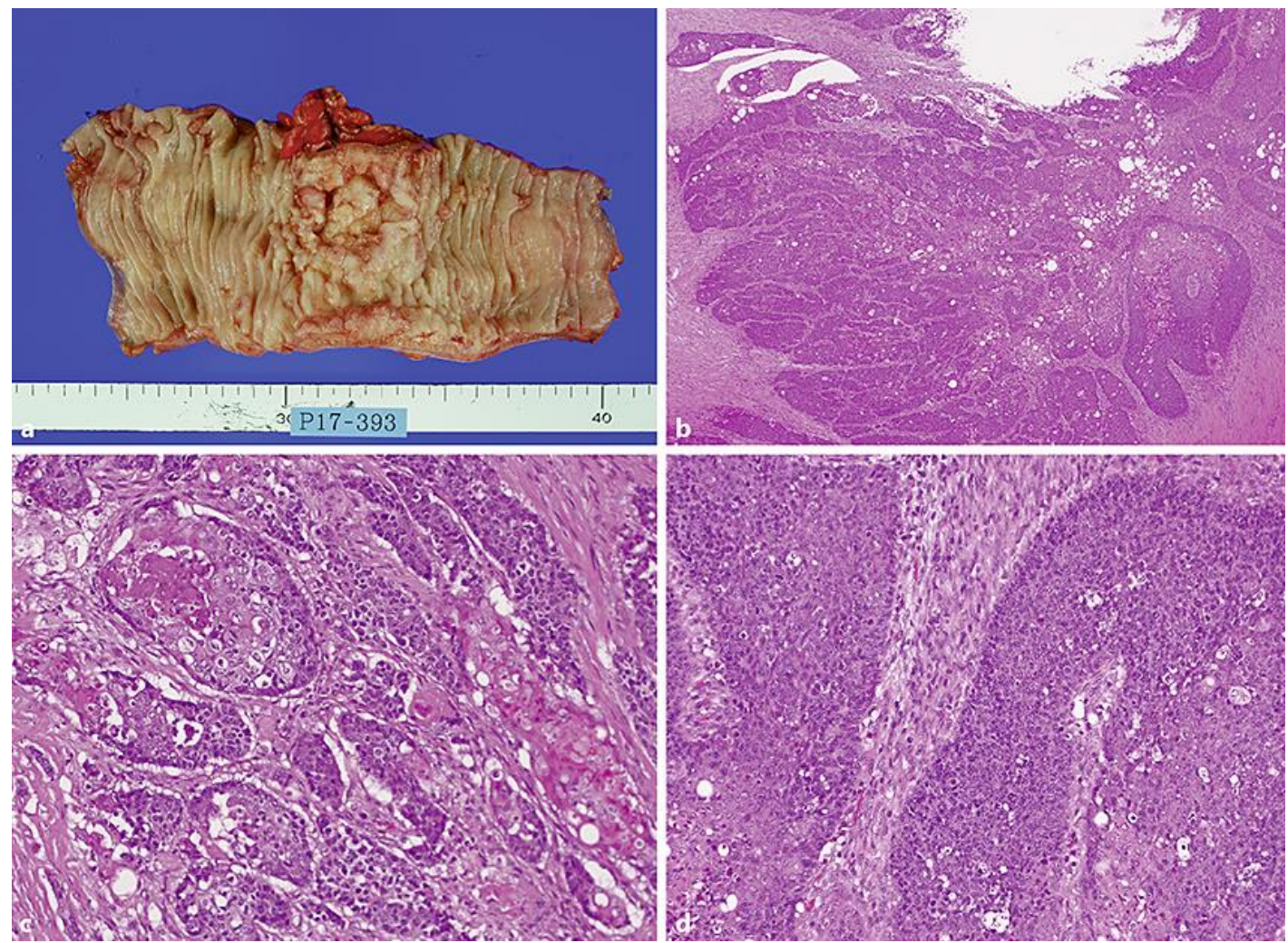

Fig. 2. a Macroscopic view of the surgically resected specimen showing a cancer measuring $3.5 \times 3.5 \mathrm{~cm}$ at the descending colon. $\mathbf{b}-\mathbf{d}$ Microscopic examination of the resected specimen. $\mathbf{b}$ Morphology on routine staining. The tumor consisted of squamous architecture in the form of keratinization and cancer pearl (c) and round to polygonal tumor cells with pleomorphic nuclei, fine granular chromatin, and prominent nucleoli arranged in diffuse sheets with an insular pattern (d). b H\&E, ×40. c H\&E, ×200. d H\&E, ×100. 


\section{Case Reports in Gastroenterology}

\begin{tabular}{l|l}
\hline Case Rep Gastroenterol 2018;12:240-246 \\
\hline DOI: 10.1159/000488194 & $\begin{array}{l}\text { ○ 2018 The Author(s). Published by S. Karger AG, Basel } \\
\text { www.karger.com/crg }\end{array}$ \\
\hline
\end{tabular}

Munakata et al.: Mixed Neuroendocrine Carcinoma and Squamous Cell Carcinoma of the Colon: Case Report and Literature Review
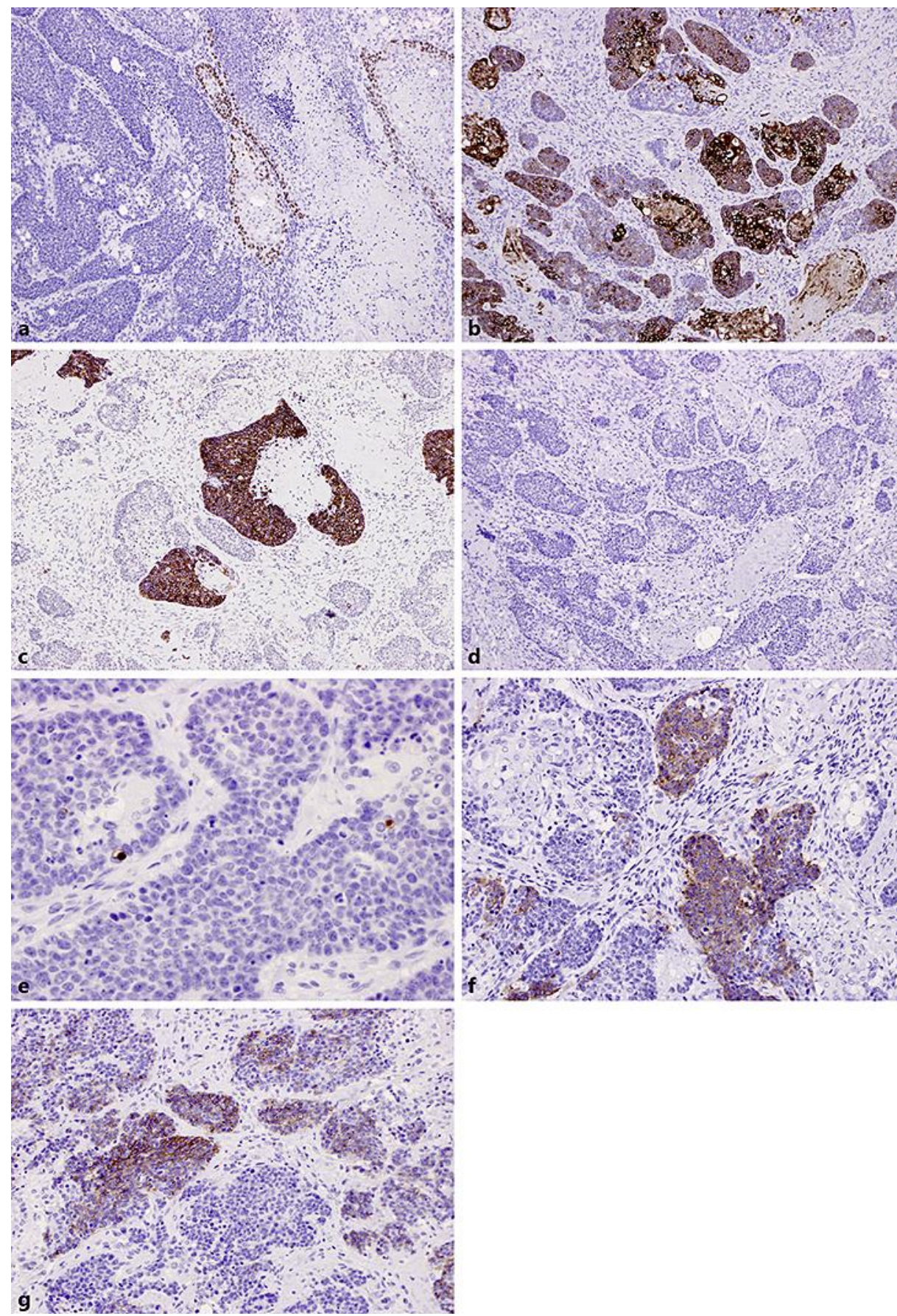

Fig. 3. a, b The tumor showed diffuse immunopositivity for p40 ( $\times 40)(\mathbf{a})$ and CA5/6 $(\times 100)(\mathbf{b})$. c, d The tumor also showed immunopositivity for CK7 (c) but not CK20 $(\times 100)$ (d). e Immunohistochemical staining for chromogranin A $(\times 400)$ revealed little reaction. $\mathbf{f}, \mathbf{g}$ Immunohistochemistry showed that the tumor was diffusely positive for synaptophysin $(\times 200)(f)$ and CD56 $(\times 200)(g)$. 